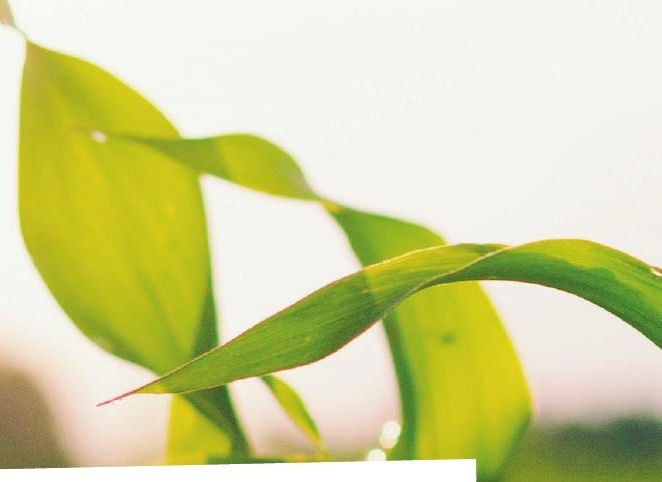

\title{
HOW CAN UNDERSTANDING
}

\section{PLANTS AND MICROORGANISMS}

\section{HELP FEED THE WORLD?}

\begin{abstract}
DR DAVIDE BULGARELLI, A SCIENTIST OF THE UNIVERSITY OF DUNDEE, BASED AT THE JAMES HUTTON INSTITUTE IN SCOTLAND, IS STUDYING THE INTERACTION BETWEEN PLANTS AND SOIL MICROBES. THE FINDINGS COULD BOOST SUSTAINABLE FOOD PRODUCTION AND HELP ACHIEVE GLOBAL FOOD SECURITY
\end{abstract}

By 2050, the global population is expected to increase to 9.8 billion and, by 2100, 11.2 billion. Such numbers are concerning because there will be billions more mouths to feed and current farming and agricultural processes are considered inadequate to cope with this increased demand. With this in mind, researchers are turning their attention to developing novel strategies that will enable crops to be grown in a sustainable way to ensure global food security.

To develop these strategies, it is vital that plant scientists conduct investigations to understand more about plants and how they interact with their environment and other organisms. Dr Davide Bulgarelli, a researcher of the University of Dundee based at the James Hutton Institute in Scotland, is a plant scientist who is studying interactions between plants and soil microbes. It is hoped that by understanding how plants communicate with bacteria in soil, it may be possible to manipulate these interactions for the benefit of plants and improve crop yields.

WHAT IS THE SPECIFIC FOCUS OF DAVIDE'S RESEARCH?

In one current project, Davide and his team are focused on understanding more about barley - the fourth most cultivated cereal crop in the world. It is known that plants and animals do not exist alone, but rather interact with different microorganisms, known as the microbiota. There are millions of different bacteria in the soil clumped around plant roots, in what scientists call the rhizosphere, and Davide wants to understand the role of microbiota in the rhizosphere. "The rhizosphere microbiota can help plants to grow better and healthier," explains Davide. "It is, therefore, fair to say that the rhizosphere microbiota is a key determinant of global food security."

\section{WHAT METHODS AND TECHNIQUES HAVE DAVIDE AND HIS TEAM USED IN THEIR INVESTIGATIONS?}

Because the microorganisms that Davide and his team are studying are invisible to the naked eye, they need to use state-of-the-art techniques to aid their investigations. One means of doing this is to study the DNA of microbes. DNA can be thought of as a blueprint for every living organism. "Like a 21 st century microscope, state-of-the-art sequencing technology allows us to look inside microbial cells and identify building blocks of the DNA blueprint, which scientists call genes," says Davide. "Each gene has its own 'signature' called a sequence and this varies depending on the organisms we are looking at. It is like a fingerprint: a given gene or a given gene sequence can be used as a proxy for a given microorganism."

Using these techniques, Davide is able to understand which microbes are in the soil and what they can do. The team can then compare this information with other microbiota in different crops and soils to gain a fuller picture of the relationship between plants and soil microbes.

\section{WHAT HAS THE STUDY REVEALED ABOUT HEALTHY PLANT \\ MICROBIOTA?}

One of the key findings of the team's work is that there is no one-size-fits-all scenario when it comes to the plant microbiota. Every crop has its own microbial signature, where a set of microbes can colonise the rhizosphere and other plant tissues. "One useful way of looking at our findings is to think of the plant as the conductor of an orchestra," says Davide. "It fine tunes the composition of the individual microbial members of the microbiota - if we can understand the music sheets, we can 



\section{ABOUT PLANT SCIENCES}

Plant sciences, which was once more often known as botany, is the systematic and scientific study of plants. Researchers in the field focus on the structure and biochemistry of plants, the physiological processes that happen in them, and their relationship with the surrounding environment and other organisms.

The history of plant science is long and varied. Aristotle is said to have done work in identifying plants in $400 \mathrm{BC}$ and is seen as the originator of the scientific study of life, but it wasn't until the 17th century that plant science became a significant field of study. In the late 17th century, Robert Hooke contributed to the building of one of the most elegant - and effective - microscopes, which provided a means of investigating cells and eventually led to the discovery of single-celled organisms.

Davide highlights three key historical figures in plant sciences who provide inspiration for his team's current work and are worthy of further reading:

- Gregor Mendel was a 19th century monk whose pioneering work in genetics, using peas, now forms the basis of Davide's day-to-day investigations.

- Barbara McClintock is another innovative plant geneticist. She discovered the 'jumping genes' of maize and was awarded a Nobel prize for work in this field (in 1983).
- Norman Borlaug conducted research that formed the basis of the 'Green Revolution' - research that led to increased agricultural production worldwide. He was awarded the Nobel Peace Prize in 1970 the first of many accolades he received.

\section{WHAT ARE THE MOST PRESSING ISSUES FOR TODAY'S PLANT \\ SCIENTISTS?}

Although the work of Norman Borlaug was instrumental in tackling hunger around the world, hunger and malnutrition are still issues for many parts of the world today and the challenge for a fair and sustainable future is still on. The ever-increasing global population will continue to stretch resources around the world and plant science is seen as one of the most effective ways of overcoming these challenges. "By 2050, agricultural production will need to more than double to ensure there is enough to feed everyone," explains Davide. "Current approaches are not sufficient or sustainable, so it is vital that we can develop novel strategies to ensure a fairer and safer future for everyone." Understanding how plants function in the environment is fundamental to designing these strategies.

\section{PLANT SCIENCE IS HIGHLY} MULTIDISCIPLINARY. HOW IMPORTANT IS COLLABORATION TO RESEARCH?

Davide says that he cannot imagine a working environment without the types of interactions he is engaged with on a near-daily basis. His research involves working with many partners from several countries across Europe and the rest of the world, and these collaborations are extremely important to the success of his project. "Engaging with different life and working experiences provides you with different visions on science," says Davide. "This is exactly what you need when you are working to overcome a difficult situation and trace new paths in the course of your research."

\section{WHO OR WHAT HAS INSPIRED DAVIDE IN THE FIELD OF PLANT SCIENCE?}

Davide grew up in an agricultural area and always valued the importance of food. However, it wasn't until he was in his third year at university that he really began to consider a career in plant sciences. "Back then, I had to take an internship outside of the faculty and I was lucky enough to end up in one of the top-level plant sciences research institutes in my country," explains Davide. "The camaraderie among scientists, the scientific debates, the thrill of a new scientific discovery ... it all suddenly clicked and I realised that was what I wanted to be part of and study for the rest of my academic life!"

\section{HOW TO BECOME A PLANT SCIENTIST}

- Science and Plants for Schools (http://www.saps.org.uk/) is an organisation that promotes plant science at school level. It includes a wealth of information about how to go on to study it at university and has a range of science clubs documenting student activities (http://www.saps.org.uk/secondary/science-club-activities).

- The UK Plant Sciences Federation (http://www.plantsci.org.uk/) forms part of the Royal Society of Biology. It promotes the importance of plant science and how it benefits society, and provides a forum for discussion, debate and information exchange.

- Plant scientists can earn between $£ 22,000$ and $£ 55,000$ per annum, depending on their level of experience. Salaries of more senior professionals, such as university professors or leading scientists at major agro-biotech companies, may exceed these figures. 


\section{HOW DID DR DAVIDE BULGARELLI BECOME A PLANT SCIENTIST?}

DID YOU ALWAYS KNOW YOU

WANTED TO BE A SCIENTIST OR

DID YOU HAVE OTHER AMBITIONS?

When I was a kid, I played with LEGO a lot

of the time! I wasn't always indoors, though

- I still have memories of playing seemingly never-ending ball games with my friends. At that time, becoming a scientist wasn't something I ever really considered - I think becoming a professional sportsman was my first career choice. Over time, as that dream became more and more unlikely, I was drawn to science and, eventually, got into the field of plant science. If I hadn't become a scientist, I honestly don't know what I would have done.

WHAT ATTRIBUTES HAVE ENABLED YOU TO BECOME A SUCCESSFUL SCIENTIST?

I think it is worth highlighting that there isn't a perfect or unique recipe to guarantee success. In my career, I have learned that it is important to stand up for yourself and take setbacks on the chin; they shouldn't be thought of as a dead end, but as a starting point for a path to new achievements. You should listen to advice, but be in control of your own choices where possible - these points have certainly been the main drivers behind my career.

HOW DO YOU OVERCOME ANY OBSTACLES AND FRUSTRATIONS YOU FACE?

Sometimes you just need to unplug yourself for a day. Once you return, the problem may well still be there, but it is possible you will see a new solution that you were unable to see before. Seeking advice from colleagues who have experienced similar situations has helped me a lot in the past.

DO YOU HAVE AN OVERARCHING CAREER AMBITION?

Yes! Ultimately, I hope that my team's work will contribute to achieving global

\section{PATHWAY FROM SCHOOL TO PLANT SCIENTIST}

Davide says that plant sciences clicked for him when he was at university, but that a good starting point for a career in plant sciences is developing a curiosity for disciplines like biological sciences, mathematics and genetics.

\section{2 or 3 A levels, or equivalent, including biology}

A degree in botany, ecology, environmental science, plant biology or plant science https://nationalcareers.service.gov.uk/job-profiles/botanist

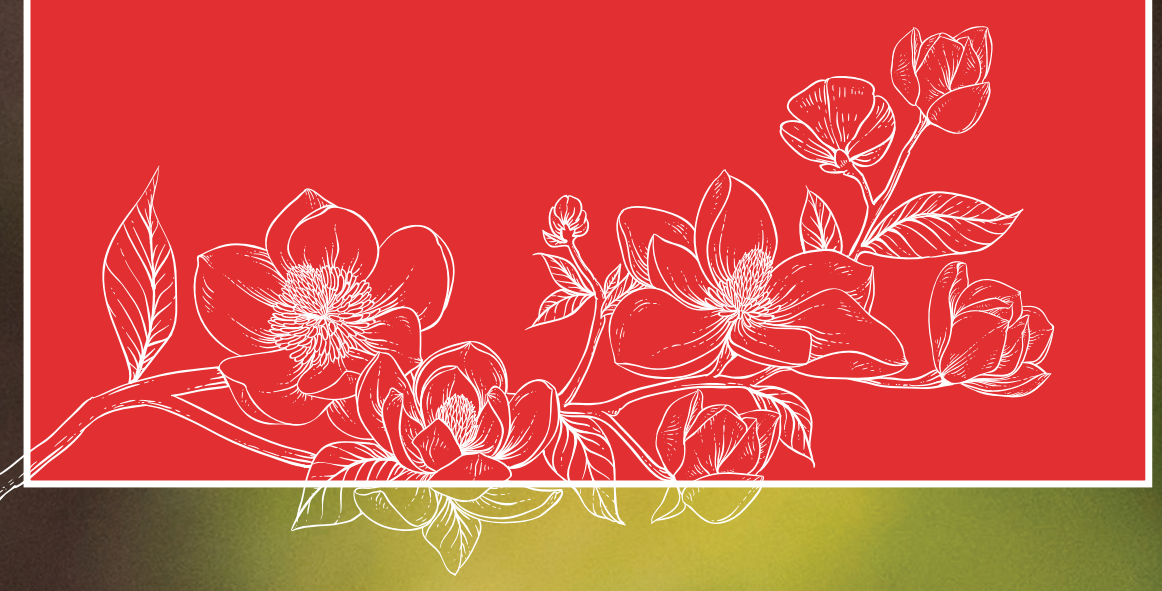

food security - that is my main motivation and career ambition.

FINALLY, WHAT INTERESTS DO YOU HAVE OUTSIDE WORK?

I still play football, although it tends to be with my colleagues now rather than the friends I played with as a child! I am also an avid reader of crime novels, so I read those whenever I get the chance. I love travelling with my family, too.

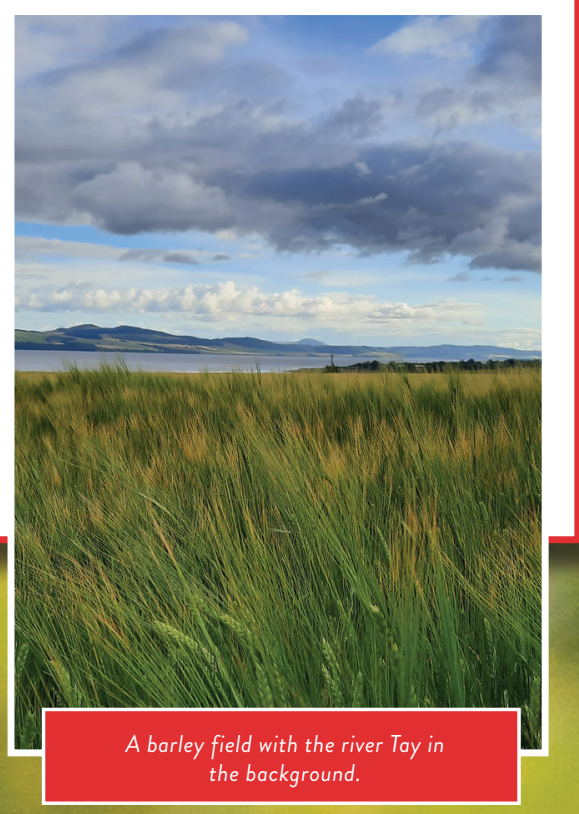

